\title{
Edzett üveg dinamikus és nagy hőmérsékletű, kvázistatikus vizsgálata
}

\section{Dynamic and High Temperature Quasi-static Examination of Tempered Glass}

\author{
Leveles Borbála, ${ }^{1}$ Kemény Alexandra, ${ }^{2}$ Katona Bálint ${ }^{3}$ \\ Budapesti Müszaki és Gazdaságtudományi Egyetem, Gépészmérnöki Kar, Anyagtudomány és Technológia \\ Tanszék, Budapest, Magyarország \\ ${ }^{1}$ borbala.leveles@edu.bme.hu \\ 2 alexa@eik.bme.hu \\ ${ }^{3}$ katona@eik.bme.hu
}

\begin{abstract}
In everyday use glass materials cause a lot of damage or injuries when broken, as fracture mechanism and damage runoff can not be predicted precisely. To gain knowledge on this issue, we studied the properties of tempered glass. The glass test samples were exposed to two types of destructive evaluations: normal and high temperature three-point bending and room temperature dynamic experiments with colliding small steel spheres. The evaluation showed that high temperature experiments are in correlation with sharp fracture edges, and dynamic impact creates shell featured circular crack propagation which prevents the spreading of the radial cracks, so the damage is concentrated to a small area.
\end{abstract}

Keywords: tempered glass, quasi-static bending, fracture surface, dynamic.

\section{Összefoglalás}

A mindennapokban használt üvegek törése sok esetben okoz károkat és sérüléseket, mivel nehezen megbecsülhető eltérő körülmények között a törési tulajdonsága és a károsodás végbemenetele. Ennek közelebbi megismerése céljából kutatásunk során edzett üveg tulajdonságait vizsgáltuk. Az üveg próbatestek kétféle roncsolásos anyagvizsgálaton estek át: szobahőmérsékleten és nagy hőmérsékleten végzett hárompontos hajlításnak és szobahőmérsékletű dinamikus vizsgálatnak, melyben nagy sebességű acélgolyó becsapódásának tettük ki a mintákat. Megállapítottuk, hogy nagy hőmérsékleten végzett terhelés hatására a próbatesteknek a hőmérséklet növelésével arányosan egyre élesebb a töretfelületük, illetve dinamikus behatás következtében körkörös repedésterjedéssel kagylós jellegű töretkép keletkezik, amely megakadályozza a radiális repedések terjedését, így csak kis területen megy végbe károsodás.

Kulcsszavak: edzett üveg, kvázistatikus hajlítás, töretfelület, dinamikus behatás.

\section{Bevezetés}

A hétköznapokban számos területen találkozunk üvegből készült épületelemekkel, tárgyakkal. Elsősorban biztonságtechnikai szempontból érdemes vizsgálni különböző üvegek törési mechanizmusait és a kialakult töretfelületeket különböző balesetek és károk csökkentése érdeké- ben [1, 2]. A legnagyobb mechanikai terhelésnek kitett üvegtípus az edzett üveg, ezért kutatásunkban ezek törési tulajdonságaival foglalkozunk [3]. Az üvegnek mint alapanyagnak általában nagy a nyomószilárdsága, azonban igen rideg, tehát nem szenved maradandó alakváltozást tönkremenetel előtt. Ez azt jelenti, hogy lényegében érzékelhető előjel nélkül következik be a törés [4]. 
Az amorf vagy más néven nemkristályos anyagok szilárdulása nem értelmezhető ugyanúgy, ahogy a kristályosoké. Hűtés során az üveg folyamatosan egyre viszkózusabb lesz, de nincs egy konkrétan meghatározható hőmérséklet, amikor folyadék halmazállapotból szilárddá alakul [5-7].

Amikor egy nemkristályos anyag emelt hőmérsékletről hűl le, belső feszültségek, úgynevezett hőfeszültségek alakulhatnak ki az anyagban, amelynek oka a hütési sebesség és termikus zsugorodás eltérése a felület és a belső régiók között. Ezek a feszültségek befolyásolják a mechanikai tulajdonságokat. Az üvegek anyagában szándékosan létrehozott nyomófeszültség létrehozását az üveg edzésének nevezik. Kalcium-nátrium üvegek esetében $\sim 600^{\circ} \mathrm{C}$-os hőn tartás után gyors hütéssel lehet létrehozni a belső feszültségeket. Ekkor a felület hőmérséklete gyorsabban csökken, majd üvegesedés után rideggé válik és öszszezsugorodik, míg a belső részek még melegek és lassan hủlnek. Ebben az esetben a külső rész viszkozitása megnő és kevésbé tud alakváltozást szenvedni, miközben a belső rész még zsugorodna a hủlés hatására. Mivel a zsugorodást korlátolja a külső rész, a két felület között húzó- és nyomófeszültség alakul ki (1. ábra) [7].

$\mathrm{Az}$ edzett biztonsági üveg tönkremenetele a legkevésbé veszélyes, hiszen amellett, hogy sokkal nagyobb erőhatásra van szükség a töréshez, annak létrejöttekor kicsi, de nem éles darabokra esik szét az anyag, amelyeket a középső fólia az esetek többségében egyben is tart [8]. Ez jelentősen biztonságosabb, mint a kezeletlen síküveg, mivel sokkal kisebb személyi sérülés keletkezhet $[9,10]$.

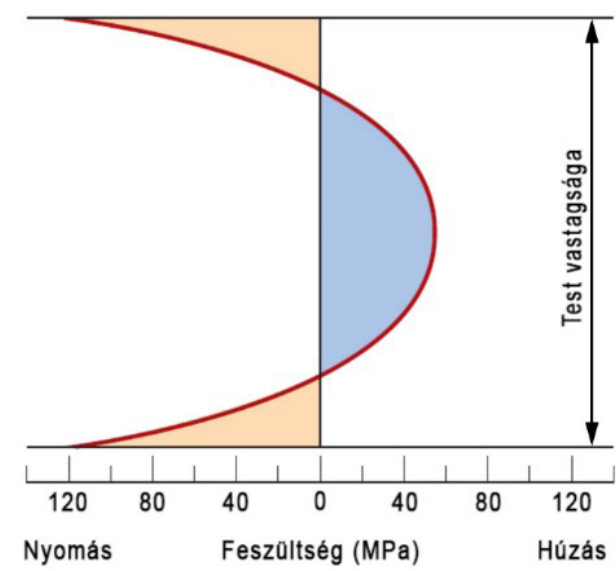

1. ábra. Keresztmetszeti maradófeszültség-eloszlás szobahömérsékletü edzett üveg lemezben [7] alapján
Rideg anyagok kvázistatikus károsodása általában egy jellemzően tükörsima, kisméretű felületből indul ki, melynek környezetében a szakirodalomban „mist”-nek nevezett fátyolos felület képződik, ezt követi a „hackle” tűs, térben terjedő, a tükörsima felülethez képest radiális irányú repedés [11-13].

Az üvegek dinamikus behatásra jellemzően kétféle módon károsodhatnak. Létrejöhetnek radiális repedések, amelyek hengeres próbatest esetén a felület normálisának sugárirányában terjednek, két vagy több részre bontva a felületet [14]. Ezek jellemzően minden üveg károsodásánál fellépnek. Beszélhetünk továbbá körkörös repedésekről is, ezek általában megállítják a radiális repedéseket, így egy jelentősen kisebb kiterjedésű károsodás lép fel az anyagban. Utóbbi károsodási mód az edzett üvegekre jellemző [15, 16].

\section{Eszközök és módszerek}

Kutatásunk célja az edzett üveg töretfelületének és törési tulajdonságainak megismerése által megbecsülhetővé tenni adott mechanikai terhelés és hőmérséklet hatására bekövetkező károkat és törési folyamatokat.

A hajlítóvizsgálatokhoz hagyományos kalcium-nátrium síküvegből készítettünk $5 \times 15 \times 100$ mm-es hasáb alakú próbatesteket (1. táblázat). A próbatesteket élcsiszoltuk, majd pedig edzettük $610{ }^{\circ} \mathrm{C}$-on 2 órán át, végül áramló levegőn hütöttük le. A mintákat három különböző hőmérsékletre hevítettük $\left(23^{\circ} \mathrm{C}, 300^{\circ} \mathrm{C}, 600^{\circ} \mathrm{C}\right)$, majd kvázistatikus terheléssel hárompontos hajlítóvizsgálatot végeztünk rajtuk Instron 5965 univerzális anyagvizsgáló berendezéssel, $1 \mathrm{~mm} / \mathrm{min}$ terhelési sebességgel.

1. táblázat. A felhasznált üveg anyagösszetétele

\begin{tabular}{|c|c|c|c|c|c|}
\hline & $\mathbf{S i O}_{2}$ & $\mathbf{N a}_{2} \mathbf{O}$ & $\mathbf{C a O}$ & $\mathbf{M g O}$ & $\mathbf{A l}_{2} \mathbf{O}_{\mathbf{3}}$ \\
\hline $\begin{array}{c}\text { Mennyiség } \\
(\%)\end{array}$ & 74 & 16 & 5 & 4 & 1 \\
\hline
\end{tabular}

A kvázistatikus vizsgálatok mellett pneumatikus lövőszerkezettel dinamikus terhelővizsgálatot végeztünk $700 \mathrm{~mm}$ távolságról, Ø6 mm-es acélgolyó $100 \mathrm{~m} / \mathrm{s}$ sebességű becsapódásával. Ezeket a vizsgálatokat $5 \mathrm{~mm}$ vastag biztonsági üvegből készült személygépjármű-szélvédőn végeztük, amely kétrétegű, a rétegek között polivinil-butirál (PVB) fóliával laminált. A szélvédő befoglaló méretei: $1000 \times 1600$ mm, alátámasztása a két rövidebb él mentén történt. A hagyományos síküveg próbatestek szintén $5 \mathrm{~mm}$ vastagok voltak, befoglaló 
méretei 200×200 mm, szintén két él mentén alátámasztva.

A kísérletek elvégzése után a töretfelületeket Olympus SZX16 sztereomikroszkóppal és Zeiss EVO MA10 pásztázó elektronmikroszkóppal (SEM) vizsgáltuk, továbbá a dinamikus behatás lefolyását FASTCAM SA5 model 775K-C3 nagy sebességű kamerával rögzítettük.

\section{Az eredmények értékelése}

A kvázistatikus vizsgálatok során az edzett síküvegek jellegzetesen törtek, egyértelműen nem meghatározható repedéskiindulási pontokkal. A próbatestek a törés mentén szobahőmérsékleten egyáltalán nem élesek, viszont több irányba indul meg egyszerre a repedés (2. ábra). Élesnek nevezzük azt, amikor síkmetszetben az él csúcspontját a szomszédos két völgy alsó pontjával összekötő egyenesek hajlásszöge $<90^{\circ}$. Különösen érdemes kiemelni a $300^{\circ} \mathrm{C}$-on létrejött töretet, amelyben a repedés egy kisméretű síkfelületből indul ki, majd a térben terjed tovább (2. ábra c, d). A $600{ }^{\circ} \mathrm{C}$-on hajlított próbatest már nem mutatja a kisebb hőmérsékleten jellemző tulajdonságokat, és éles felület képződik, amely veszélyes (2.ábra e, f). Ennek oka, hogy az üvegek edzése $610{ }^{\circ} \mathrm{C}$-on történt, amely a $600{ }^{\circ} \mathrm{C}$-os hőmérséklethez már igen közel áll, így az edzés során kialakult belső feszültségek csökkennek.

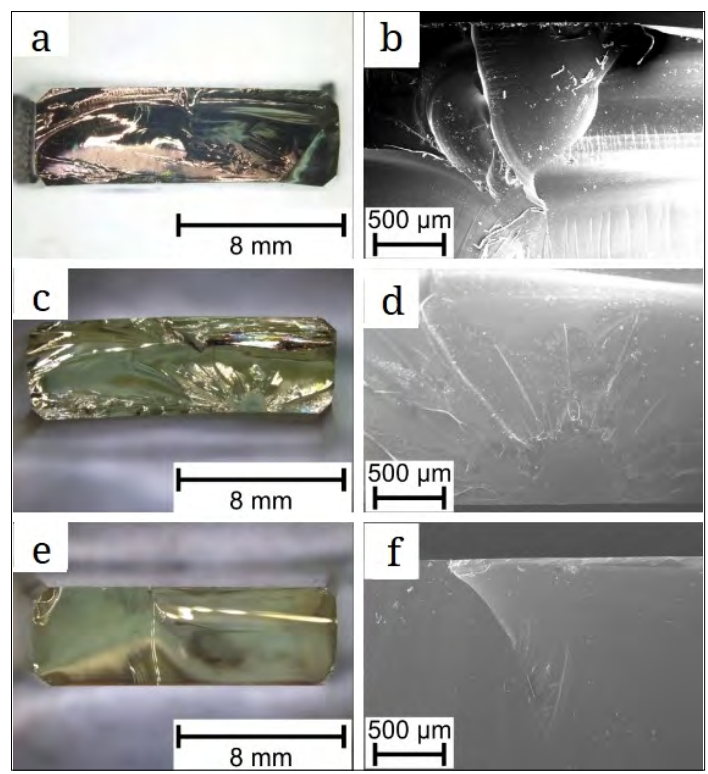

2. ábra. Hárompontos hajlítóvizsgálat során létrejött töretfelületek sztereomikroszkópos képe balra és SEM-felvétele jobbra $\left(23^{\circ} \mathrm{C} a, b ; 300{ }^{\circ} \mathrm{C} c, d ; 600{ }^{\circ} \mathrm{C}\right.$ $e, f)$
A hárompontos hajlítóvizsgálatok eredményét feldolgozva meghatározható a különböző hőmérsékleteken mért, a próbatestet jellemző hajlítószilárdság (1) és rugalmassági modulus.

$$
R_{m h}=\frac{M}{K}=\frac{\frac{F_{m} L}{4}}{\frac{a b^{2}}{6}}=\frac{3 F_{m} L}{2 a b^{2}}
$$

ahol:

$F_{m}$ - a maximális fellépő erő (N),

$L$ - az alátámasztási távolság (mm),

$a$ - a vizsgált próbatest szélessége ( $\mathrm{mm})$,

$b$ - a vizsgált próbatest magassága (mm).

A 3. ábra mutatja ezek jellegét. Megfigyelhető, hogy mindkét jellemző a hőmérséklet növelésével csökken. Ez alapján elmondható, hogy az anyag vizsgált mechanikai tulajdonságai romlanak, és az üvegek felhasználhatósága korlátozott az extrém körülmények között. A jelenség magyarázható azzal, hogy a $600{ }^{\circ} \mathrm{C}$ már üvegesedési hőmérséklet fölött van a vizsgált üvegeknél, azaz jelentősen lecsökken a viszkozitása.

A dinamikus vizsgálatok esetén a becsapódáskor a biztonsági üvegekre jellemző töret alakul ki 0,100 ms alatt. Az ebben lévő repedések a későbbiekben nem terjednek tovább (4. ábra). A becsapódási ponton finom üvegpor jelenik meg, hiszen ott roncsolódik az anyag a leginkább.

Megfigyelhető, hogy a becsapódás környezetében körkörös, pókhálószerű repedések jöttek létre, amelyek megállítják a további radiális repedésterjedést, így a károsodás csak kis területre terjed ki. Fontos még megjegyezni, hogy a szélvédők külső oldalát vizsgáltuk, hiszen a belső oldala felől nem jellemző a dinamikus behatás.

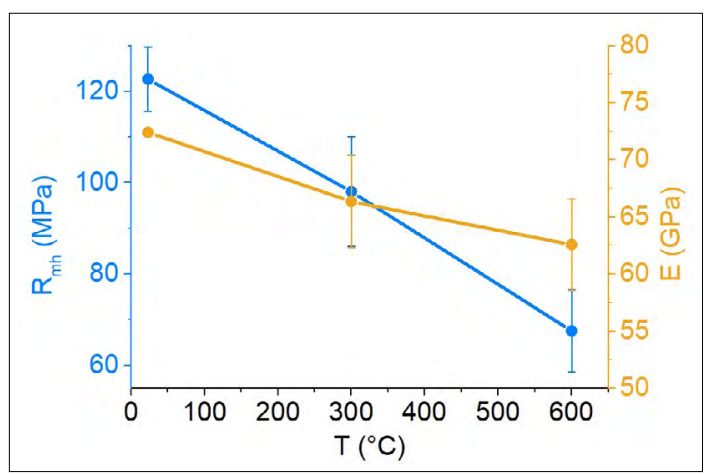

3. ábra. A hajlítószilárdság és rugalmassági modulusz hőmérsékletfüggése 
A vizsgálatok során a belső üvegréteg nem károsodott.

A dinamikus vizsgálatokat elvégeztük ugyanolyan alapanyagú nem edzett üvegeken is, referenciaképp (5. ábra). Megfigyelhető, hogy több repedés radiálisan terjed, és ezek a minta széléig kifutnak, majd az üveglap különböző méretü, éles szilánkokra esik szét.
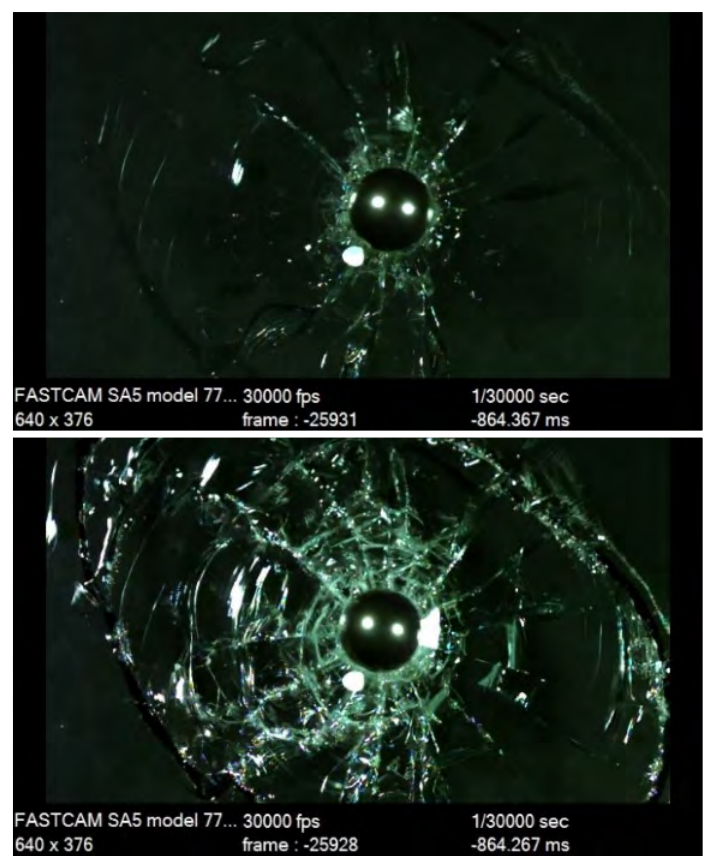

4. ábra. Nagy sebességü kamerás felvétel a golyó becsapódásáról a becsapódás pillanatában és 0,100 ms-mal később

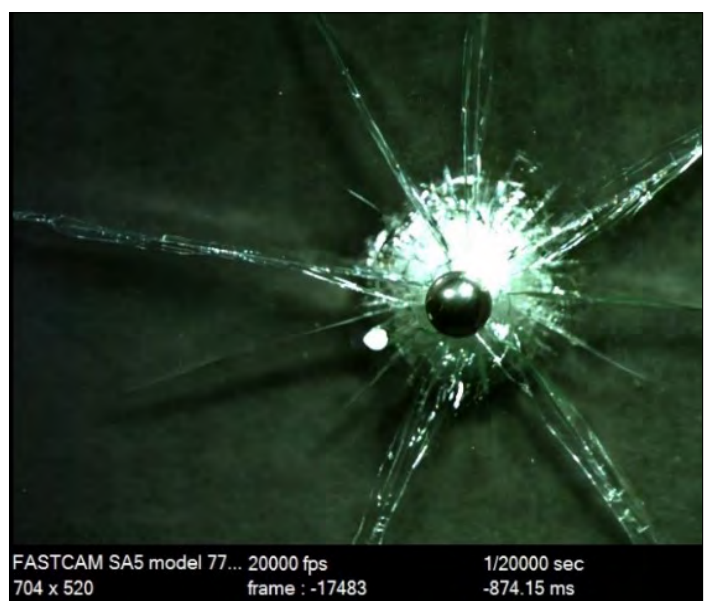

5. ábra. Ca-Na síküveg dinamikus terhelés hatására létrejött tönkremenetele

\section{Következtetések}

A kvázistatikus vizsgálat terhelési folyamatában a vizsgált, edzett üvegek apró darabokra törtek, és tompa élek, elágazó repedések jellemezték szobahőmérsékleten. A kevésbé sérülésveszélyes élek létrejötte összefüggésben van a sok repedéssel és az apró leválásokkal a belső felszültségek következtében, így a belső feszültségek miatt tompább felület jön létre. $300{ }^{\circ} \mathrm{C}$-on még nem jelentkezik lényeges különbség a töretek jellege között, $600{ }^{\circ} \mathrm{C}$-on a töretfelület kevésbé felosztott, viszont a töretélek hegyesek, érintésre élesek.

A dinamikus vizsgálatokkal megfigyeltük az edzett üveg válaszait nagy sebességű, pontszerű behatásra. A szélvédők a kis hatókörü, nagy sebességű behatásoknak (pl. felpattanó kőnek) is jól ellenállnak, ekkor a törés kis térfogatra koncentrálódik. A külső üveg és a PVB-réteg energiaelnyelő képessége akkora, hogy vizsgálatunk alatt a második, azaz belső üvegrétegig már el sem jutott a károsodás.

Összességében megállapítható, hogy a kalcium-nátrium alapanyagú edzett üveg nem alkalmazható biztonságtechnikai célból nagy hőmérsékletre hevítés után, azonban kis hőmérsékleten ideálisabb a tönkremenetele, azaz jelentősen biztonságosabb a hagyományos, ugyanolyan alapanyagú üvegnél.

\section{Köszönetnyilvánítás}

Az eredmények közzétételéhez anyagi hozzájárulást nyújtott a BME Tudományos Diákköri Bizottságának TDK-pályázata.

\section{Szakirodalmi hivatkozások}

[1] Chen J. et al.: Experimental investigation on the radial and circular crack propagation of PVB laminated glass subject to dynamic out-of-plane loading. Engineering Fracture Mechanics, 112113. (2013) 26-40.

https://doi.org/10.1016/j.engfracmech.2013.09.010

[2] Huang J. et al.: A study on correlation of pedestrian head injuries with physical parameters using in-depth traffic accident data and mathematical models. Accident Analysis and Prevention, 119. (2018) 91-103.

https://doi.org/10.1016/j0ap.2018.07.012

[3] Xu J. et al.: Experimental study on mechanical behavior of PVB laminated glass under quasi-static and dynamic loadings. Composites: Part B, 42. (2011) 302-308.

https//doi.org/10.1016/j.compositesb.2010.10.009

[4]VogelW.: Glass Chemistry.SecondEdition,SpringerVerlag Berlin, Heidelberg-Berlin, 1994. 
[5] Shackelford J. F., Doremus R. H.: Ceramic and Glass Materials - Structure, Properties and Processing. First Edition, Springer Science + Business Media LLC, New York, 2008. https://doi.org/10.1007/978-0-387-73362-3

[6] Callister W. D. Jr.: Materials Science and Engineering - An Introduction. Seventh Edition, John Wiley \& Sons Inc, New York, 2007.

[7] Kingery W. D., Bowen H. K., Uhlmann D. R.: Introduction to Ceramics. Second Edition, John Wiley \& Sons, New York, 1976. https://doi.org/10.1149/1.2133296

[8] Nielsen J. H., Bjarrum M.: Deformations and strain energy in fragments of tempered glass: experimental and numerical investigation. Glass Structures \& Engineering, 2. (2017) 133-146. https://doi.org/10.1007/s40940-017-0043-8

[9] Fennelly L. J.: Effective Physical Security. Fifth Edition, Butterworth-Heinemann, Oxford, 2017.

[10] Yong Peng et al.: Investigation of the fracture behaviors of windshield laminated glass used in highspeed trains. Composite Structures, 207. (2019) 29-40.

https://doi.org/10.1016/j.compstruct.2018.09.009

[11] Tandon R., Glass S. J.: Fracture initiation and fragmentation in chemically tempered glass.
Journal of the European Ceramic Society, 35. (2015) 285-295.

https://doi.org/10.1016/j.jeurceramsoc.2014.07.031

[12] Freiman, S. W., Wiederhorn, S. M., Mecholsky, J. J. Jr.: Environmentally enhanced fracture of glass: a historical perspective. Journal of the American Ceramic Society, 92/1. (2009) 1-112. https://doi.org/10.1111/j.1551-2916.2009.03097.x

[13] Bradt R. C.: The Fractography and Crack Patterns of Broken Glass. Journal of Failure Analysis and Prevention, 11. (2011) 79-96. https://doi.org/10.1007/s11668-011-9432-5

[14] ISO/TS 20746: Dentistry. Determination of the strength of dental amalgam by the Hertzian indentation strength (HIT) method, 2016.

[15] Ahearn D. L. III et al.: Fracture patterns of impact resistant glass panel laminates with annealed and heat strengthened glass plates. Ceramic Transactions Series, 199. (2007) 383-396. https://doi.org/10.1002/9781118144152.ch31

[16] Knight C. G., Swain M. V., Chaudhri M. M.: Impact of small steel spheres on glass surfaces. Journal of Materials Science, 12. (1977) 1573-1586. https://doi.org/10.1007/BF00542808 